\title{
A Framework of Reference for Evaluating User Experience When Using High Definition Video to Video to Facilitate Public Services
}

\author{
Andreea Molnar, Vishanth Weerakkody, Ramzi El-Haddadeh, \\ Habin Lee, and Zahir Irani \\ Brunel University, Kingston Lane, Uxbridge, UB8 3PH, Middlesex, United Kingdom \\ \{Andreea.Molnar, Vishanth. Weerakkody, Ramzi.El-Haddadeh, \\ Habin. Lee, Zahir. Irani\} abrunel .ac.uk
}

\begin{abstract}
This paper proposes the use of high definition video to video as a means to facilitate the adoption of public services. High definition video can be delivered over the public Internet infrastructure by using a Right of Way platform that guarantees no interference from unwanted traffic. In this paper, we discuss the benefits of using high definition video to video communication in the public sector to facilitate services such as health, education and city experience/administration. Drawing from the dominant theories on Information Communication Technology we then propose a framework of reference to evaluate user experience of such services based on the Unified Theory of Acceptance and Use of Technology 2 (Venkatesh et al., 2012), the Information Systems success model (DeLone \& McLean, 1992) and inclusion of the perception on information privacy.
\end{abstract}

Keywords: public services, video to video, user experience, evaluation framework.

\section{Introduction}

Despite the fact that it was introduced over a decade ago as a mainstream mechanism for the delivery of public services, electronic government has failed to fulfil initial expectations (Chadwick, 2009; Ferro \& Molinari, 2010). To alleviate this problem, several projects have used other channels of service delivery such as mobile applications (Abdelghaffar \& Magdy, 2012) or digital TV (da Silva et al., 2012). Although successful, these initiatives are still in pilot stages and their impact has yet to be proven on a broad scale.

Furthermore, the problems encountered during the adoption and diffusion of public services are not uniform. Simple customer facing services such as payments for services, fines or renewals of applications through the use of e-government have been successfully adopted, while more complex services are struggling with being accepted. Indeed, the research literature suggests that average citizens often prefer to have face-to-face contact when dealing with complex public services. This is particularly true for complex services such as health, education, and social or domestic 
services such as social security, housing, or employment (Andreassen et al., 2007; Santana et al., 2010). Among the problems that online services face is that they are distant and impersonal (Pavlou, 2003). Furthermore, there is no assistance offered to the citizens when they have problems using them (Ahmad et al., 2012; Venkatesh et al., 2011).

In this article, we argue that enhancing government services with high definition (HD) video to video (V2V) has the potential to offer citizens better and more personalised services, similar to those offered by face-to-face, but maintaining the advantages of electronic services, i.e. citizens being able to access them regardless of their location and delivery channel. V2V will be used to facilitate service delivery (such as teaching from a remote location, connecting a patient with a specialist), but also in assisting citizens with their queries, or with the usage of an online service. The potential benefits of facilitating public services through $\mathrm{V} 2 \mathrm{~V}$ range from an easier usage to saving someone's life by providing the relevant stakeholders with adequate information when it is needed. To be able to improve the delivery of HD V2V on public Internet infrastructure, a new technology has to be introduced to alleviate some of the shortcomings that current video communication faces. However, due to the novelty of such technology, an established method to evaluate it does not exist. In this paper, we draw from existing theories to evaluate technology adoption and diffusion in order to propose a framework of reference to evaluate the user experience for $\mathrm{V} 2 \mathrm{~V}$ facilitated services.

The rest of this paper is organised as follows. First, we briefly present how HD $\mathrm{V} 2 \mathrm{~V}$ can be used on public infrastructure and the potential of using high definition video on the Internet for providing public services and the associated benefits that they can offer society. Second, the existing literature on technology adoption and diffusion is presented. We draw conclusions from this literature in order to propose a framework of reference for evaluating user experience. The next section discusses the conceptual development in relation to the proposed V2V framework. Finally, we conclude by outlining future directions for the use of $\mathrm{V} 2 \mathrm{~V}$ services in the public sector.

\section{High Definitions Video to Video and Its Applications on Public Infrastructure}

Although V2V communication has been previously used in public infrastructure by using applications such as Skype, FaceTime etc., it is often limited by technological constraints that affect delivery and have as consequences low image definition, delays in delivery etc. that put strain on user experience. In this article, we propose a LiveCity environment, where citizens communicate with each other and their governments anytime, anywhere using HD V2V on public infrastructure. HD V2V delivery will be implemented by using Right of Way (RoW) to guarantee a lack of interference from non-desired traffic, hence alleviating some of the problems imposed by current video delivery over public infrastructure. The LiveCity environment will be community driven and aims at improving core public services such as education, 
health, and city experience, empowering the citizens of a city to interact with each other in a more productive, efficient and socially useful way by using HD V2V.

Several public services could benefit from being enhanced with HD V2V. Some such services are Health, City Experience/Administration, and Education. For example, in health, a V2V service will be used for communicating live video images from the scene of a fatal accident to the emergency room of a hospital where an expert consultant can guide (real time) the paramedics on the ground on the best course of life saving treatment. Likewise, HD V2V can be used in tele-medicine where a doctor based in his/her surgery room can be guiding a patient at home on self-treatment (such as using eye drops to treat glaucoma). V2V will also be used to improve city administration where a municipality worker can assist a citizen with their service needs by guiding the citizen over the video link. Similarly, V2V can be used in education scenarios where teachers can assist pupils to complete their homework using a video link; or groups of students can have interactive debates (between schools) using a high definition video link. Furthermore, HD video will be used to promote the cultural heritage and art in a museum environment where people can view and interact with museum artefacts while at the same time interacting with museum workers regardless of their location.

\section{Framework of Reference for Evaluating the User Experience in LiveCity}

Due to the innovative nature of $\mathrm{V} 2 \mathrm{~V}$ usage in the context of the LiveCity environment, the evaluation is considered complex due to the difficulty of quantifying the benefits and inefficiencies. There does not exist an established way of evaluation yet. Therefore, we draw from existing theories on evaluating technology adoption and diffusion in order to propose an evaluation framework for LiveCity. Drawing on the dominant theories applied in Information and Communication Technology (ICT), a proposal for an integrated model of evaluation of $\mathrm{V} 2 \mathrm{~V}$ services is developed, based on the Unified Theory of Acceptance and Use of Technology 2 (Venkatesh et al., 2012), the Information Systems success model (DeLone \& McLean, 1992) and inclusion of the perception on information privacy. The information privacy concept is introduced due to the fact that in the event of wide adoption of $\mathrm{V} 2 \mathrm{~V}$ on the Internet, potential users may be exposed to information security and privacy concerns.

State of the art key performance indicators for LiveCity are developed from a behavioural perspective. Hence, the related performance indexes refer to the assessment of LiveCity services from an end-users' viewpoint, and specifically with regards to the acceptance of using the V2V service and satisfaction from the service. As a result, we draw from the state of the art for technology adoption and associated behavioural evaluation.

Several researchers have proposed indicators for evaluating user satisfaction with innovative and/or new technology based services. Johnston (1995) compiled 18 determinants of service quality that have been used for assessing electronic services' (e-services) quality including availability, reliability, friendliness, functionality, 
access, aesthetics, etc. Parasuraman et al. (1988) have developed a widely accepted model namely SERVQUAL for measuring service quality that includes five dimensions: tangibles, reliability, responsiveness, assurance, and empathy. Information system researchers have adopted and modified the SERVQUAL model for e-service quality, including dimensions of website design, reliability, fulfilment, security, responsiveness, personalization, information (accuracy, comprehensibility, etc.) and empathy (Li and Suomi, 2009). Similarly, Zeithaml et al. (2001) adopts the SERVQUAL model for e-service quality evaluation and proposes 11 dimensions: access, ease of navigation, efficiency, flexibility, reliability, personalization, security/privacy, responsiveness, assurance/trust, site aesthetics, and price knowledge. Moreover, several information system researchers have applied technology acceptance theories in order to evaluate e-services from a user's perspective. During the past three decades there have been numerous studies regarding ICT acceptance and numerous information system (IS) acceptance studies have focused on the reasons why potential users accept or do not accept technology. Many research models have been developed and empirically validated, mainly including: The theory of Reasoned Action (TRA) (Fishbein and Ajzen, 1975), Social Cognitive Theory (SCT) (Bandura, 1986), Technology Acceptance Model (TAM) (Davis, 1989) and extended TAM 2 (Venkatesh and Davis, 2000), TAM 3 (Venkatesh and Bala, 2008), Theory of Planned Behaviour (TPB) (Ajzen, 1991), Model of PC Utilisation (Thompson et al, 1991), Motivation Model (Davis et al, 1992), the model combining TAM and the TPB (Taylor and Todd, 1995), the Innovation Diffusion Theory (IDT) (Rogers, 1995).

Table 1. Prominent Models used to study User Behaviour in Technology Adoption

\begin{tabular}{|l|l|}
\hline \multicolumn{1}{|c|}{ Model } & \multicolumn{1}{c|}{ Reference } \\
\hline Theory of Reasoned Action (TRA) & Fishbein and Ajzen (1975) \\
\hline Technology Acceptance Model (TAM) & Davis (1989) \\
\hline Motivational Model (MM) & Davis, Bagozzi and Warshaw (1992) \\
\hline Theory of Planned Behaviour (TPB) & Ajzen (1991) \\
\hline $\begin{array}{l}\text { Combination of Technology Acceptance } \\
\text { and Theory of Planned Behaviour mod- } \\
\text { els (combined TAM - TPB) }\end{array}$ & Taylor and Todd (1995b) \\
\hline $\begin{array}{l}\text { Model of PC Utilization (MPCU) } \\
\text { Innovation Diffusion Theory (IDT) }\end{array}$ & $\begin{array}{l}\text { Thompson, Higgins and Howell } \\
\text { (1991) }\end{array}$ \\
\hline Social Cognitive Theory (SCT) & Moore and Benbasat (1991) \\
\hline
\end{tabular}

The line of research in technology acceptance models culminates with the Unified Theory of Acceptance and Use of Technology (UTAUT) that was developed by (Venkatesh et al., 2003). The UTAUT aims to explain user intentions for using an information system. The subsequent usage behaviour and the model have been empirically examined by numerous studies. The UTAUT model integrates eight previously developed models and theories that relate to technology acceptance and use. Venkatesh et al. (2003) observed that IT researchers had a choice among a multitude 
of models and were confronted to choose constructs across models or choose an ideal model, thus ignoring the contribution from alternative ones. Therefore researchers compared the eight dominant models in explaining technology acceptance behaviour that have been previously used by researchers and scholars. The eight prominent models included are outlined in Table 1.

Another dominant stream of research in information systems and technology evaluation focuses on information system (IS) success. This includes several conceptual and empirical studies. In 1979, an assessment of IS research factors was conducted by Zmud (1979) to review issues addressed by most academics and practitioners concerning the influence of individual differences upon management information system design, implementation, and usage. In 1983, Bailey and Pearson (1983) outlined that evaluating and analysing computer user satisfaction is performed as an aspiration to improve the productivity of information systems by organizational management. According to the authors, productivity in computer services means both efficiently supplied and effectively utilized data processing outputs (Bailey and Pearson, 1983). In 1984, a study was conducted by Ives and Olson (1984) that emphasizes the importance of user involvement. After a decade, a study followed by Davis (1989) developed TAM. This explained the relationship among information system beliefs (e.g. perceived usefulness and ease of use, attitudes, and behavioural intentions and systems usage). DeLone and McLean (1992) reviewed over 180 articles and came up with the information systems success model that consisted of information quality, system quality, use, user satisfaction, individual impact, and organizational impact. In 1995, Goodhue and Thompson (1995) developed the task-technology fit model. The authors argued that the model services as the basis for a strong indicative tool to assess whether an information system including systems, policies, IS staff, and services in a given organization are meeting user needs. Among the above mentioned studies, DeLone and McLean's IS success model (1992) has gained great attention from scholars and widespread attention in the information success literature.

Given the above discussed context for the study of information technology and systems adoption, we present the two most widely accepted evaluation models, UTAUT and IS success model, which will be used to investigate the Key Performance Indicators (KPIs) for LiveCity from a behavioural perspective.

\subsection{The Unified Theory of Acceptance and Use of Technology}

The Unified Theory of Acceptance and Use of Technology provides a useful tool for managers that aim at assessing the likelihood of success for new technology introduction and helps them understand the drivers of technology acceptance in order to proactively design interventions targeted at users that might be less inclined to adopt and use new systems respectively (such as, training, marketing, etc.). The UTAUT model consists of three indirect determinants of behavioural intention, and two direct determinants of use behaviour. The three core constructs in the UTAUT model that declare to impact behavioural intention (BI) directly are: (1) performance expectancy, (2) effort expectancy, and (3) social influence. Intention to use and facilitating conditions (FC) are declared to impact indirectly on use behaviour. UTAUT includes four 
moderators (i.e. age, gender, experience and voluntariness of use), which contribute to a better understanding of the complexity of technology acceptance by individuals. Figure 1 illustrates UTAUT's core constructs.

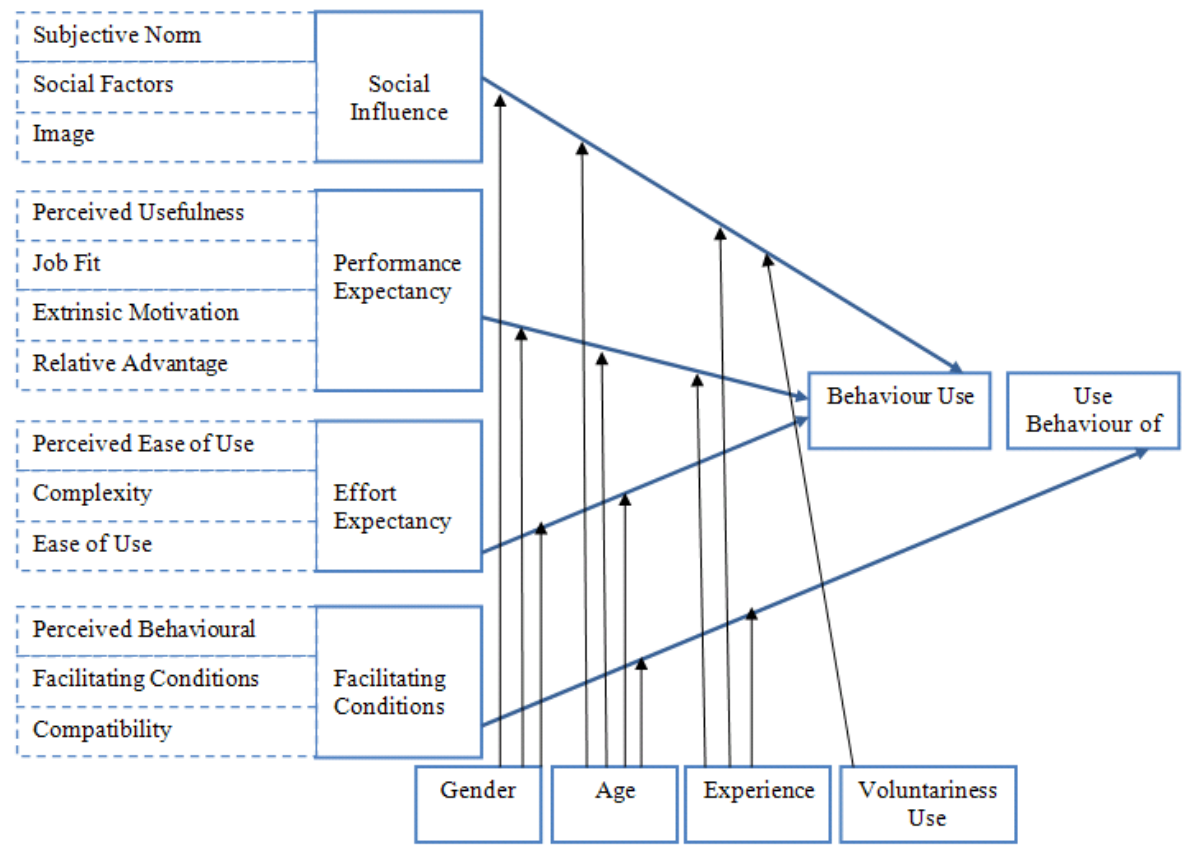

Fig. 1. UTAUT's Constructs and Root Core of Constructs

Additionally, the UTAUT model suggests the following: (1) gender and age moderate the relationship between performance expectancy and behavioural intention, (2) gender, age, and experience moderate the relationship between effort expectancy and behavioural intention, (3) gender, age, experience and voluntariness are suggested to moderate the relationship between social influence and behavioural intention, and (4) age and experience are declared to moderate the relationship between facilitating conditions and behaviour intention.

UTAUT2 (Figure 2) is an extension of UTAUT "to study acceptance and use of technology in the consumer context" (Venkatesh et al., 2012). UTAUT2 adds three more constructs that affect BI: (1) hedonic motivation, (2) price value, and (3) habit. Voluntariness use is no longer kept as one of the moderators, as in the consumer context most activities are voluntary; hence no variation will occur by including it (Venkatesh et al., 2012). A link is also added between facilitating conditions and behavioural intention. 


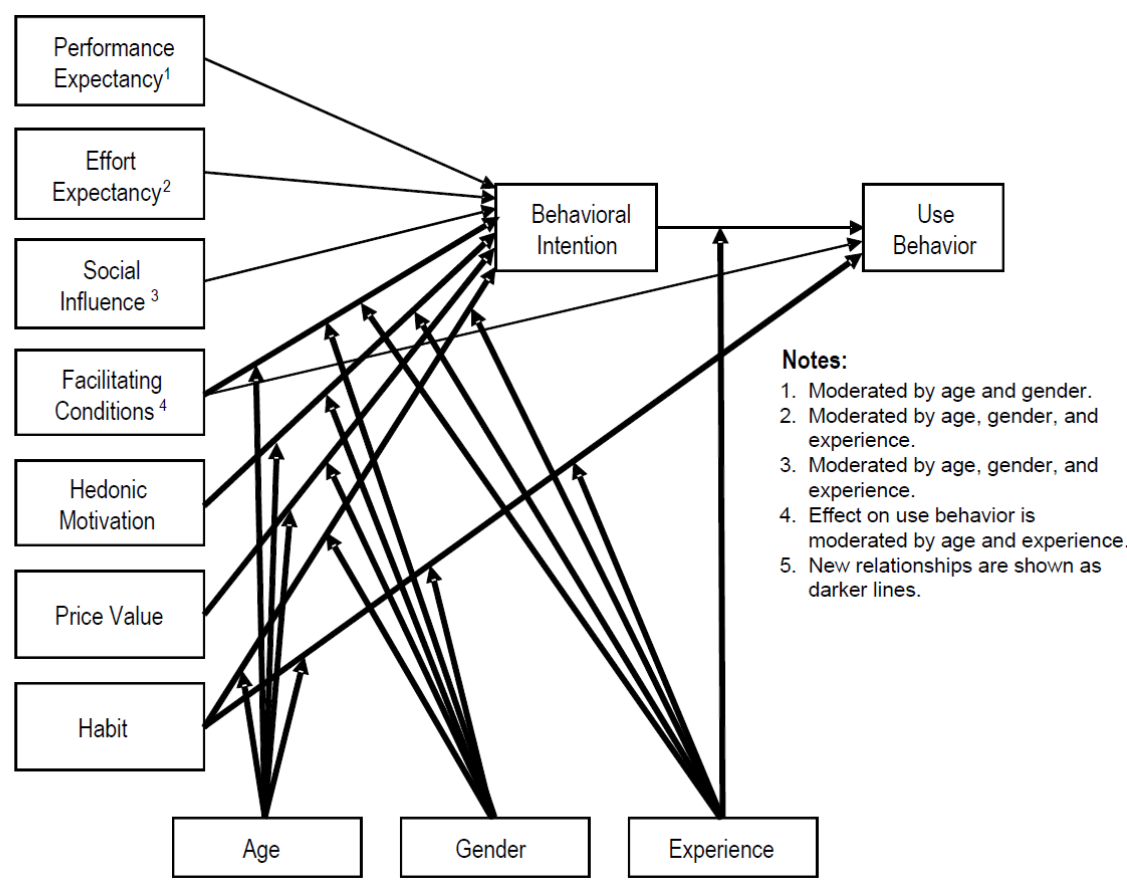

Fig. 2. UTAUT2 (Venkatesh et al., 2012)

\subsection{IS Success Model}

One of the most popular information systems success assessment models that resulted in highly significant contributions in the research literature is the DeLone and McLean IS success model conceptual model (IS Success model). The IS success model categorizes existing IS success measures under six dimensions (Gable, Sedera and Chan, 2003; Seddon, 1997). As Gable, Sedera and Chan (2003) note the development of IS success models, such as the DeLone and McLean model, has been an important contribution toward our improved understanding of IS management.

The IS success taxonomy and its six success categories are based on a process model of information systems (DeLone and McLean, 1992). Additionally, strong cause and effect relations exist among the six dependent variables. The six dimensions are interrelated, resulting in a success model that illustrates that causality flows in the same direction as the information process does (DeLone \& McLean, 2002). The six major variables of the IS success model are:

1. system quality

2. information quality

3. use

4. user satisfaction

5. individual impact

6. organizational impact 
In the IS Success model, system quality measures technical success, information quality measures semantic success and use, user satisfaction, individual impact, and organizational impact measure effectiveness success of the system measured. Figure 3 illustrates the IS Success model.

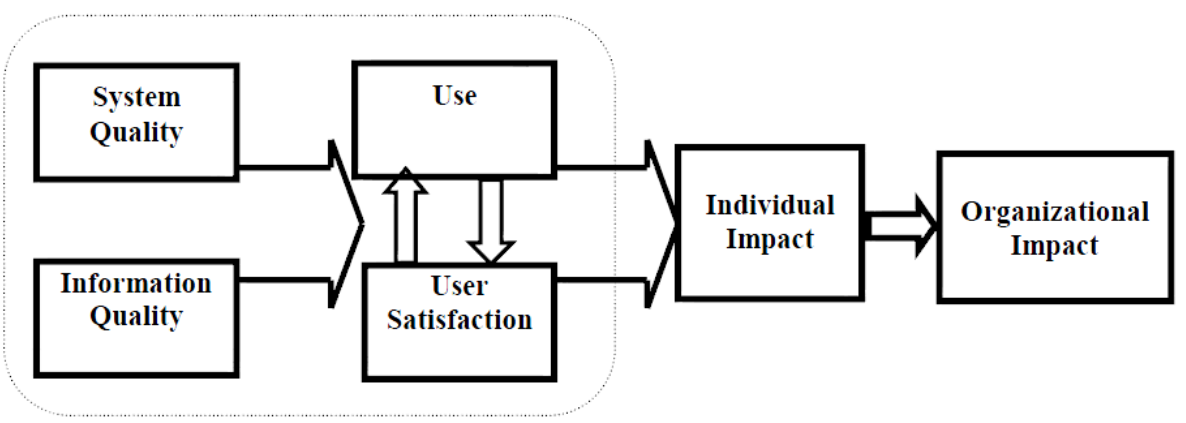

Fig. 3. DeLone and McLean IS Success Model (1992)

One of the strongest criticisms about the IS Success model is the lack of service quality among variables. According to Pitt, Watson and Kavan (1995), there is a danger that researchers will mis-measure IS effectiveness if they do not include in their assessment criteria a measure of IS service quality. Service is an important part of information systems departments; thus, service quality is a critical measure of information system effectiveness (Van Dyke, Kappelman and Prybutok, 1997). As a result, in order to measure information system effectiveness properly, many researchers believed that service quality should be included in the IS success model as a success measure (Kettinger and Lee, 1997; Myers, Kappelman and Prybutok, 1997; Pitt, Watson and Kavan, 1997). Pitt, Watson and Kavan (1997, p.210) posit that "the IS community needs to be aware of problems that might be experienced in using an instrument to measure so critical a construct as IS service quality".

Having realised the importance of e-services, DeLone and McLean (2003) outlined that in frequently used systems not only the benefits to the users, but also the quality of the system should be considered as well. In response to the calls of other researchers that criticized the original model, and due to the advent and growth of Internet based e-services, DeLone and McLean (2003) decided to add service quality to their new model as an important dimension of IS success noting the significance of customer service in the e-services environment. Therefore, in an attempt to contribute towards a universal model, DeLone and McLean (2003) introduced their updated model after ten years of its first induction in 1992. The model includes six success dimensions, and holds that the constructs of information quality, system quality, and service quality individually jointly affect the factors of use and user satisfaction, whereas user satisfaction and use jointly affect net benefit. Figure 4 illustrates the updated DeLone and McLean Success Model. 


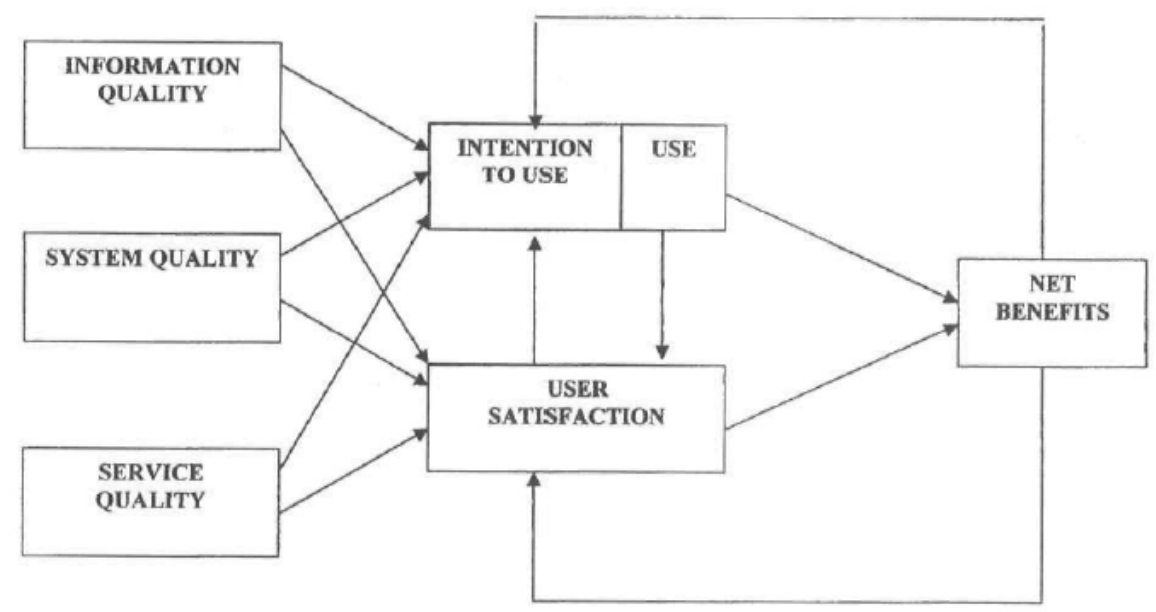

Fig. 4. Updated DeLone and McLean IS Success Model

The updated model of DeLone and McLean (2003) includes six success dimensions to measure the success of a system in the e-services domain. The six major variables of the 2003 IS success model are:

1. System quality, which measures the desired characteristics of an e-Commerce system. It refers to the quality of (usability, availability, reliability, adaptability, and response time (e.g., download time),

2. Information quality, which measures the e-Commerce content issues, the dimension of this variable are (personalization, currency, relevance, reliability, completeness, easy to understand and secured for (to gain user's trust when conducting a transaction via the internet),

3. Service quality, which is the "overall support delivered by the service provider, applies regardless of whether the support is delivered by the information systems' department or a new organizational unit or is outsourced to an internet service provider" (DeLone \& McLean, 2004, p. 34),

4. Usage, which measures everything from a visit to a web site and navigation within the site to information retrieval and execution of a transaction,

5. User satisfaction, which measures customers' opinions of an e-Commerce system and should cover the entire experience cycle of customers from information retrieval to purchase, payment, receipt, and service, and

6. Net benefits that capture the balance of the positive and negative impacts of eCommerce on customers, suppliers, employees, organizations, markets and even society as a whole.

Hu et al. (2005) attempted to establish a suitable and systematic appraisal framework of public sector e-services success based on the IS Success Model presented by DeLone and McLean in 1992, which is relevant to the LiveCity project. Table 2 summarizes the relevant KPIs for evaluating the LiveCity project. 
Table 2. IS Success Model Factors

\begin{tabular}{|c|c|c|c|}
\hline \multirow{5}{*}{$\begin{array}{l}\text { System } \\
\text { Quality }\end{array}$} & Reliability & $\begin{array}{l}\text { The dependability of system opera- } \\
\text { tions }\end{array}$ & \multirow{5}{*}{$\begin{array}{l}\text { (Wixom and } \\
\text { Todd, 2005) }\end{array}$} \\
\hline & Flexibility & $\begin{array}{l}\text { The way the system adapts to } \\
\text { changing demands of the user }\end{array}$ & \\
\hline & Integration & $\begin{array}{l}\text { The way the system allows data to } \\
\text { be integrated from various sources }\end{array}$ & \\
\hline & Accessibility & $\begin{array}{l}\text { The ease with which information } \\
\text { can be accessed or extracted from } \\
\text { the system }\end{array}$ & \\
\hline & Timeliness & $\begin{array}{l}\text { The degree to which the system } \\
\text { offers timely responses to requests } \\
\text { for information or action }\end{array}$ & \\
\hline \multirow{4}{*}{$\begin{array}{l}\text { Information } \\
\text { Quality }\end{array}$} & Completeness & $\begin{array}{l}\text { The degree to which the system } \\
\text { provides all necessary information }\end{array}$ & \multirow{4}{*}{$\begin{array}{l}\text { (Wixom and } \\
\text { Todd, 2005) }\end{array}$} \\
\hline & Accuracy & $\begin{array}{l}\text { The user's perception that the in- } \\
\text { formation is correct }\end{array}$ & \\
\hline & Format & $\begin{array}{l}\text { The user's perception of how well the } \\
\text { information is presented }\end{array}$ & \\
\hline & Currency & $\begin{array}{l}\text { The user's perception of the degree } \\
\text { to which the information is up to } \\
\text { date }\end{array}$ & \\
\hline \multirow{5}{*}{$\begin{array}{l}\text { Service } \\
\text { Quality } \\
\text { (SERVQUAL } \\
\text { Scale) }\end{array}$} & Tangibles & $\begin{array}{l}\text { Physical facilities, equipment, and } \\
\text { appearance of personnel }\end{array}$ & \multirow{5}{*}{$\begin{array}{l}\text { (Parasuraman, } \\
\text { Zeithaml and } \\
\text { Berry, 1988) }\end{array}$} \\
\hline & Reliability & $\begin{array}{l}\text { Ability to perform the promised } \\
\text { service dependably and accurately }\end{array}$ & \\
\hline & Responsiveness & $\begin{array}{l}\text { Willingness to help customers and } \\
\text { provide prompt ability to inspire } \\
\text { trust and confidence }\end{array}$ & \\
\hline & Assurance & $\begin{array}{l}\text { Knowledge and courtesy of em- } \\
\text { ployees and their ability to inspire } \\
\text { trust and confidence }\end{array}$ & \\
\hline & Empathy & $\begin{array}{l}\text { Caring, individualized attention to } \\
\text { firm provides its customers }\end{array}$ & \\
\hline \multirow{2}{*}{$\begin{array}{l}\text { Information } \\
\text { Use }\end{array}$} & Usefulness & $\begin{array}{l}\text { The degree to which a person be- } \\
\text { lieves that a particular information } \\
\text { system would enhance his or her job } \\
\text { performance }\end{array}$ & \multirow[t]{2}{*}{ (Davis, 1989) } \\
\hline & Ease of Use & $\begin{array}{l}\text { The degree to which a person be- } \\
\text { lieves that using a particular system } \\
\text { would be free of effort }\end{array}$ & \\
\hline \multirow{2}{*}{$\begin{array}{l}\text { User } \\
\text { Satisfaction }\end{array}$} & $\begin{array}{l}\text { Information } \\
\text { Satisfaction }\end{array}$ & $\begin{array}{l}\text { The application of that information } \\
\text { useful in enhancing work perform- } \\
\text { ance }\end{array}$ & \multirow{2}{*}{$\begin{array}{l}\text { (Wixom and } \\
\text { Todd, 2005) }\end{array}$} \\
\hline & $\begin{array}{l}\text { System } \\
\text { Satisfaction }\end{array}$ & $\begin{array}{l}\text { A degree of favourableness with } \\
\text { respect to the system and the me- } \\
\text { chanics of interaction }\end{array}$ & \\
\hline
\end{tabular}




\subsection{Integrated Model for Evaluating User Experience of LiveCity}

For the purpose of evaluating the user experience related to LiveCity technology and services, the two noteworthy models, UTAUT2 and DeLone and McLean IS Success model, are integrated based on theoretical evidence presented in the previous two sections as depicted in Figure 5 below.

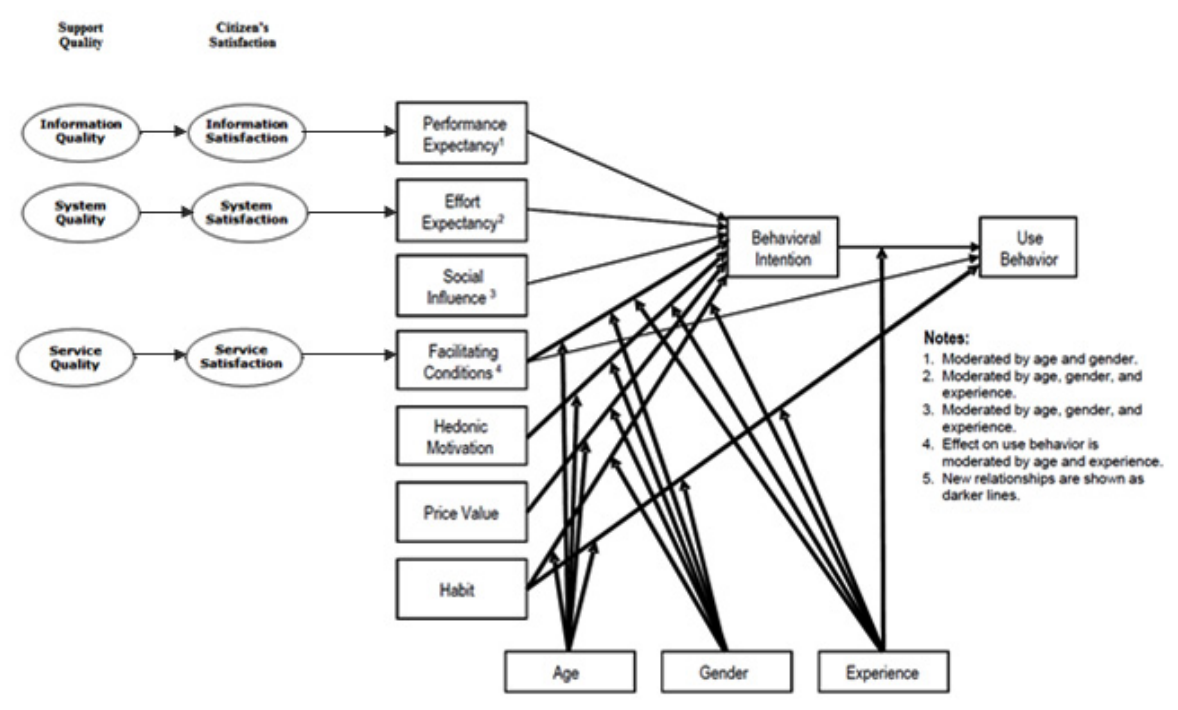

Fig. 5. Integrated Model of UTAUT and IS success model

The integrated research model presented in Figure 5 attempts to merge quality dimensions from the IS Success model together with the UTAUT2 model as antecedents for the intention to use with an attempt to reveal the role of perceived service quality towards intention to use the LiveCity application. The acceptance of the LiveCity application is defined through the behaviour intention to use the associated services. The proposed integrated research framework consists of thirteen constructs; one dependent variable and ten independent variables. The dependent variable is behaviour intention to use LiveCity services, while the independent variables are: (1) information quality, (2) information satisfaction, (3) system quality, (4) system satisfaction, (5) service quality, (6) service satisfaction, (7) social influence, (8) performance expectancy, (9) effort expectancy, (10) facilitating conditions, (11) hedonic motivation, (12) price value, and (13) habit.

Moreover, a key for adopting Internet based (V2V) services is the perceived customer or end-user perception on information security and privacy. Therefore, information privacy should be an assessment variable integrated in the model as an independent variable. For that purpose we adopt the research of Dinev and Hart (2006) who identify the factors representing elements of a privacy calculus in the e-commerce domain. 
Therefore, under the user satisfaction variables, we add the parameter of willingness to provide personal information (Figure 6).

Table 3. Information privacy construct (adopted by Dinev and Hart, 2006)

\begin{tabular}{|l|l|l|}
\hline & $\begin{array}{l}\text { Perceived Inter- } \\
\text { net privacy risk }\end{array}$ & $\begin{array}{l}\text { Perceived risk related to the disclosure of } \\
\text { personal information submitted by the relent } \\
\text { stakeholders in their specific context (use } \\
\text { cases) in general }\end{array}$ \\
\cline { 2 - 3 } $\begin{array}{l}\text { Willingness } \\
\text { to provide } \\
\text { personal in- } \\
\text { formation to } \\
\text { an e-service }\end{array}$ & $\begin{array}{l}\text { Internet privacy } \\
\text { concerns }\end{array}$ & $\begin{array}{l}\text { Concerns related to the personal information } \\
\text { submitted over the internet by the respon- } \\
\text { dent in particular }\end{array}$ \\
\cline { 2 - 3 } & Internet trust & $\begin{array}{l}\text { Trust beliefs that personal information sub- } \\
\text { mitted to V2V based services will be han- } \\
\text { dled competently, reliably, and safely }\end{array}$ \\
\cline { 2 - 3 } & $\begin{array}{l}\text { Personal Internet } \\
\text { interest }\end{array}$ & $\begin{array}{l}\text { Personal interest or cognitive attraction to } \\
\text { V2V internet content overriding privacy } \\
\text { concerns }\end{array}$ \\
\hline
\end{tabular}

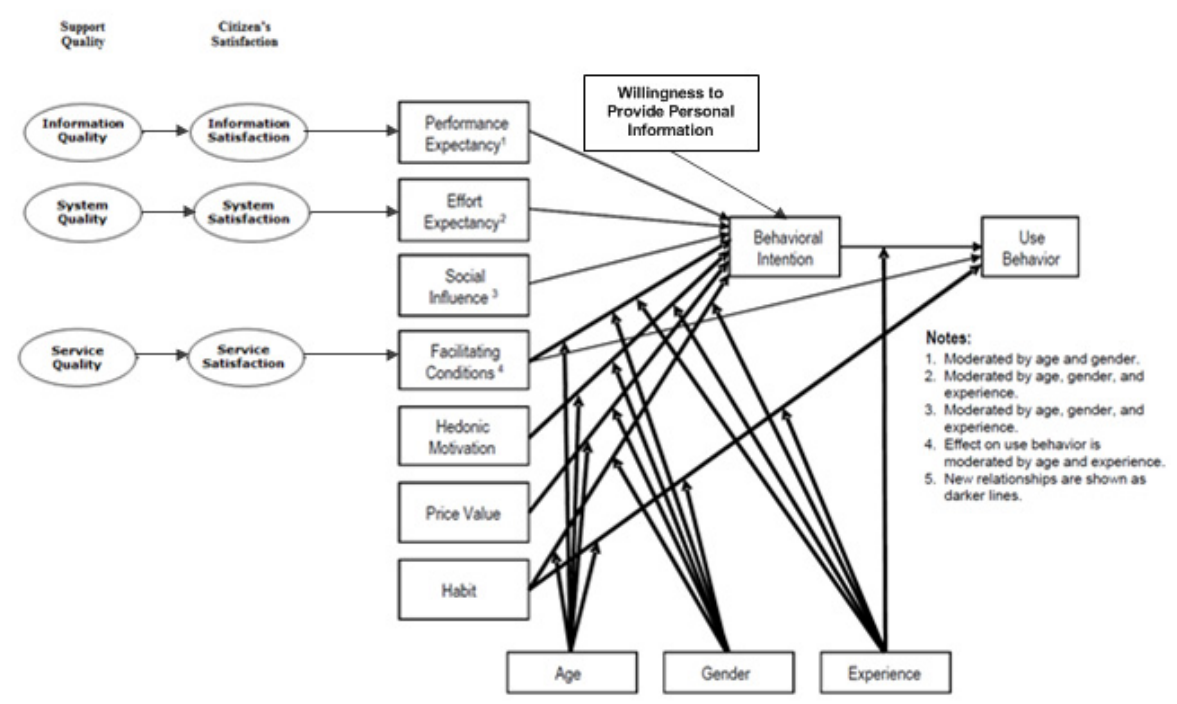

Fig. 6. Integrated model for V2V services on the Internet incorporating Trust

The model proposed in Figure 6 endeavour to merge UTAUT2 model, IS Success model and enhance them with the willingness to provide personal information. The framework consists of one dependent variable (the behaviour intention to use LiveCity services) and fourteen constructs; one dependent variable and ten independent variables. 
The dependent variable is behaviour intention to use LiveCity services, while the independent variables are: (1) information quality, (2) information satisfaction, (3) system quality, (4) system satisfaction, (5) service quality, (6) service satisfaction, (7) social influence, (8) performance expectancy, (9) effort expectancy, (10) facilitating conditions, (11) hedonic motivation, (12) price value, (13) habit and, (14) willingness to provide personal information. This reference model will serve as an evaluation framework for LiveCity users' experience.

\section{Discussion}

Taking into consideration that the use of high definition, uninterrupted V2V oriented platforms is new and yet to evolve, and limited normative literature exists specifically for the evaluation of such services. For that reason we drew upon existing literature and added constructs that are particularly important for the diffusion and adoption of Internet Based e-services such as $\mathrm{V} 2 \mathrm{~V}$ as well as other socio economic and information privacy factors that may influence the $\mathrm{V} 2 \mathrm{~V}$ offered on the Internet.

As the V2V platform will offer mostly consumer services, we draw from UTAU2 that is an extension of UTAUT to reflect the acceptance and use of technology in the consumer context. As the services covered in the LiveCity project are public services we refer to $\mathrm{Hu}$ et al. (2005) that show results from their attempt to establish a suitable and systematic appraisal framework of public sector e-services based on the IS Success Model presented by DeLone and McLean in 1992. However, the user will not adopt a service in general, hence a V2V service in particular, if they do not perceive the information exchanged as secure and private. Therefore, in the LiveCity context, for V2V services to be successfully adopted, we considered it necessary that the user is willing to provide personal information. The proposed framework will be used to evaluate behavioural intentions when using V2V services.

\section{Conclusion}

Electronic services have the potential of allowing citizens and service providers to get involved to jointly shape the design and delivery of public services facilitating openness, participation, accountability, effectiveness, and coherence of government services. However, public service adoption has not had the expected take off due to various reasons such as trust, lack of access, usability etc. This article presented how $\mathrm{HD}$ V2V can be utilised to create a LiveCity environment, in which citizens can actively be engaged in government service delivery processes. HD V2V can be realised on the public infrastructure by using a RoW that has the potential to alleviate some of the consequences of the technical constraints that currently affect video delivery. This article offers an insight on how using HD V2V can enhance public services such as health, education, and city experience and what the potential benefits and impact added by the video communication. However, due to the novelty of the technology involved, there is no established method to quantify its benefits. Therefore, we draw from previous literature and we propose a framework of reference for evaluating user experience on LiveCity by drawing from previous literature on technology adoption. 
Acknowledgements. The authors wish to acknowledge the contributions made to this article by the LiveCity consortium of partners and the European commission.

\section{References}

Abdelghaffar, H., Magdy, Y.: The Adoption of Mobile Government Services in Developing Countries: The Case of Egypt. International Journal of Information 2(4) (2012)

Ahmad, M.O., Markkula, J., Oivo, M.: Factors Influencing the Adoption of e-Government Services in Pakistan. In: Proceedings of the 9th European, Mediterranean \& Middle Eastern Conference on Information Systems (2012)

Ajzen, I.: The Theory of Planned Behavior. Organizational Behavior and Human Decision Processes 50, 179-211 (1991)

Andreassen, H.K., Bujnowska-Fedak, M.M., Chronaki, C.E., Dumitru, R.C., Pudule, I., Santana, S., Wynn, R.: European citizens' use of E-health services: a study of seven countries. BMC Public Health 7(1), 53 (2007)

Bandura, A.: The Explanatory and Predictive Scope of Self-Efficacy Theory. Journal of Social and Clinical Psychology 4 (Special Issue: Self-Efficacy Theory in Contemporary Psychology), 359-373 (1986)

Bailey, J.E., Pearson, S.W.: Development of a tool for measuring and analyzing computer user satisfaction. Management Science 29(5), 530-545 (1983)

Chadwick, A.: Web 2.0: New Challenges for the Study of E-Democracy in an Era of Informational Exuberance. I/S: A Journal of Law and Policy for the Information Society 5(1), 9-41 (2009)

Compeau, D.R., Higgins, C.A.: Application of social cognitive theory to training for computer skills. Information Systems Research 6(2), 118-143 (1995)

Davis, F.D.: Perceived Usefulness, Perceived Ease of Use, and User Acceptance of Information Technology. MIS Quarterly 13(3), 319-340 (1989)

Davis, F.D., Bagozzi, R.P., Warshaw, P.R.: Extrinsic and intrinsic motivation to use computers in the workplace1. Journal of Applied Social Psychology 22(14), 1111-1132 (1992)

da Silva, J.C.F., Barbosa, H.P., Tavares, P.B.T.A.: The Importance of digital TV for countries in development: A case study of Brazil. Journal of Communication and Computer 9, 847-851 (2012)

DeLone, W.H., McLean, E.R.: Information systems success: The quest for the dependent variable. Information Systems Research 3(1), 60-95 (1992)

DeLone, W.H., McLean, E.R.: The DeLone and McLean model of information systems success: A ten-year update. Journal of Management Information Systems 19(4), 9-30 (2003)

Dinev, T., Hart, P.: An extended privacy calculus model for e-commerce transactions. Information Systems Research 17(1), 61-80 (2006)

Ferro, E., Molinari, F.: Making Sense of Gov 2.0 Strategies: No Citizens, No Party. Journal of eDemocracy and Open Government 2(1), 56-68 (2010)

Fishbein, M., Ajzen, I.: Belief, Attitude, Intention, and Behavour: An Introduction to Theory and Research. Addison-Wesley (1975)

Gable, G.G., Sedera, D., Chan, T.: Enterprise systems success: a measurement model. In: International Conference on Information Systems, pp. 576-591 (2003)

Goodhue, D.L., Thompson, R.L.: Task-Technology Fit and Individual Performance. MIS Quarterly 19(2), 213-236 (1995)

Hu, Y., JingHua, X., JiaFeng, P., Kang, X.: A research on the framework of e-government project success. In: International Conference on Electronic Commerce, ICEC, Xian, China (2005)

Ives, B., Olson, M.H.: User involvement and MIS success: a review of research. Management Science 30(5), 586-603 (1984) 
Johnston, R.: The determinants of service quality: satisfiers and dissatisfies. International Journal of Service Industry Management 6(5), 53-71 (1995)

Kettinger, W.J., Lee, C.C.: Perspectives on the Measurement of Information Systems Service Quality. MIS Quarterly 223 (1997)

Li, H., Suomi, R.: A proposed scale for measuring e-service quality. International Journal of uand e-Service, Science and Technology 2(1), 1-10 (2009)

Myers, B.L., Kappelman, L.A., Prybutok, V.R.: A comprehensive model for assessing the quality and productivity of the information systems function: Toward a theory for information systems assessment. Information Resources Management Journal 10(1), 6-25 (1997)

Moore, G.C., Benbasat, I.: Development of an instrument to measure the perceptions of adopting an information technology innovation. Information Systems Research 6(2), 144-176 (1991)

Parasuraman, A., Zeithaml, V.A., Berry, L.L.: SERVQUAL: A multiple-item scale for measuring customer perceptions of service quality. Journal of Retailing 64(1), 12-40 (1988)

Pavlou, P.A.: Consumer acceptance of electronic commerce: Integrating trust and risk with the technology acceptance model. International Journal of Electronic Commerce 7(3), 101-134 (2003)

Pitt, L.F., Watson, R.T., Kavan, C.B.: Service quality: a measure of information systems effectiveness. MIS Quarterly, 173-187 (1995)

Pitt, L.F., Watson, R.T., Kavan, C.B.: Measuring Information Systems Service Quality: Concerns for aComplete Canvas. MIS Quarterly 21(2), 209-221 (1997)

Rogers, E.M.: Diffusion of Innovations, 4th edn. The Free Press, New York (1995)

Santana, S., Lausen, B., Bujnowska-Fedak, M., Chronaki, C., Kummervold, P.E., Rasmussen, J., Sorensen, T.: Online communication between doctors and patients in Europe: status and perspectives. Journal of Medical Internet Research 12(2) (2010)

Seddon, P.B.: A Respecification and Extension of the DeLone and McLean Model of IS Success. Information Systems Research (8), 240-253 (1997)

Taylor, S., Todd, P.: Assessing IT Usage: The Role of Prior Experience. MIS Quarterly 19(4), 561-570 (1995)

Thompson, R.L., Higgins, C.A., Howell, J.M.: Influence of experience on personal computer utilization: testing a conceptual model. Journal of Management Information Systems, 167-187 (1994)

Van Dyke, T.P., Kappelman, L.A., Prybutok, V.: Measuring information systems service quality: Concerns on the use of the SERVQUAL questionnaire. MIS Quarterly 21(2), 195-208 (1997)

Venkatesh, V., Bala, H.: Technology Acceptance Model 3 and a Research Agenda on Interventions. Decision Sciences 39(2), 273-315 (2008)

Venkatesh, V., Chan, F., Thong, J.Y.: Designing e-Government Services: Key Service Attributes and Citizens' Preference Structures. Journal of Operations Management 30, 116-133 (2011)

Venkatesh, V., Davis, F.D.: A Theorieical Extension of the Technology Acceptance Model: Four Longitudinal Field Studies. Management Science 46(2), 186-204 (2000)

Venkatesh, V., Morris, M.G., Davis, F.D., Davis, G.B.: User Acceptance of Information Technology: Toward a Unified View. MIS Quarterly 27, 425-478 (2003)

Venkatesh, V., Thong, J., Xu, X.: Consumer acceptance and use of information technology: extending the unified theory of acceptance and use of technology. MIs Quarterly 36(1), $157-178$ (2012)

Wixom, B.H., Todd, P.A.: A Theoretical Integration of User Satisfaction and Technology Acceptance. Information Systems Research 16(1), 85-102 (2005)

Zeithaml, V., Parasuraman, A., Malhorta, A.: A conceptual framework for understanding eservice quality: implications for future research and managerial practice. working paper, pp. 100-115. Marketing Science Institute, Cambridge (2001) 